\title{
RACE AS A COMPLEX ADAPTIVE SYSTEM
}

\author{
Lawrence D. Bobo \\ Department of African and African American Studies and Department of Sociology, \\ Harvard University
}

To acknowledge the socially constructed and historically contingent character of race is also to recognize it as a socially adaptive force. For some, race can only have consequence if it is a fixed construct; something rooted either in biology and nature, or instead reflecting the force of inflexibly held prejudices about those perceived as members of particular racial categories. The research reported in this issue of the Du Bois Review: Social Science Research on Race affirms the contingent and constructed meaning of race. The work illustrates how those in racially privileged positions act to secure or enhance race-related privileges. The work also shows how those in marginalized statuses individually and collectively challenge the imposition of stigma and materially disadvantaged living conditions. The work highlights how the deployment and contestation of ideas about race, as well as the larger politics and policy-making (King and Smith 2011) around such identities come to shape prevailing attitudes, ideologies and logics of race (Bobo, Kluegel and Smith 1997; Krysan 2000) as well as the dynamics of discrimination across multiple domains of life (Pager and Shepherd 2008, Reskin 2012).

Under current U.S. Supreme Court rulings race may be one factor considered by colleges and universities in admission decisions in service of attaining the compelling state interest of diverse educational environments. Pursuit of this interest is bounded by the constraint that consideration of race must not operate as a quota, rather it should reflect a nuanced assessment of a variety of criteria. While race is still an important factor, this posture represents a weakening of earlier affirmative action approaches. Yet, even this legal standard is under challenge. In particular, the most recent challenge attacks the Harvard University approach to affirmative action as discriminatory against Asians. In a carefully documented and cogently reasoned essay, political scientist Claire Jean Kim traces the narrow and politicized base of those bringing the suit against Harvard. More than this, she applies her racial triangulation theory to an understanding of how Asians and the claims made by some Asians get deployed in the evolution of an anti-Black agenda.

At this writing it is not known what will become of the Harvard affirmative action case. Even the most pessimistic forecasts tend to suggest that pursuit of diversity is 
likely to continue as a validated goal, but that a conservative U.S. Supreme Court may ultimately decide to strike race from the permissible criteria of consideration. This probability, as well as the institutionalization of diversity regimes within most business organizations of any size, leaves open many research questions regarding diversity related practices. Distinguished sociologist Herbert Gans carefully frames a series of tasks that now confront social scientists in the age of the institutionalized pursuit of diversity. One point of emphasis in Gans' approach is to view achieving diversity in various settings as a complex social process, not a singular outcome involving easily defined social groupings.

Group boundaries and hierarchies are enforced and re-constituted in many different ways and contexts. Affirmative action and diversity policies aim to reduce racial disparities in access to positions and institutions. That is, these polices aim at reducing the relevance of group racial boundaries to who possesses certain valued social outcomes (e.g., college attendance and graduation, especially at elite institutions, high status and well-paying positions in work settings). There are routinely employed cultural logics or scripts that are often deployed to shore-up or defend White privileges under challenge or changing circumstances. Similarly, there are policy changes that reconfigure power relations between dominant and subordinate communities in a way that maintains traditional racial hierarchies.

For example, legal scholar Angela Onwuachi-Willig investigates the Emmett Till murder and the Trayvon Martin murder as cases of racial boundary and hierarchy maintenance that show the influence of key intersectional racial tropes. In particular, she shows how the obligation of White men to defend "White womanhood" was a critical cultural feature of both of these tragic homicides. In both cases, the deeply ingrained stereotype of the dangerous violent Black man- a special threat to Whites in general, but especially to vulnerable White women- was an animating force in the murders themselves and in subsequent legal proceedings. In both cases, the deployment of deadly physical violence became the tool for punishing "getting out of place," and for re-asserting roles of dominance versus subordination.

The re-articulation of group power relations and therefore of group boundaries does not only play out at the individual level. Critical changes also take place at the level of institutions and social policy. For example, sociologist Louise Seamster examines how White-dominated political power structures may strip Black communities and Black-dominated municipalities of authority and resources to control their own affairs. The case in point is the state of Michigan which has enacted some of the most stringent receivership or state-appointed "emergency manager" legislation for financially strapped municipalities. Seamster shows how the law ends up being applied almost exclusively to majority Black localities. Moreover, the case study illustrates the effective end to democratic rights and voice for both local elected Black officials as well as the mass Black public in Benton Harbor, Michigan. Instead, a sort of "White urban regime" takes control of decision-making and resources in a fashion that actually worsens the circumstances of the city. Relatedly, sociologists Brianna Remster and Rory Kramer consider the impact of mass incarceration on political representation. They focus on legislative districts in the state of Pennsylvania. Their results indicate that mass incarceration of African Americans has shifted political power from urban areas that are disproportionately Black to more rural areas that are disproportionately White.

Deeply implicated in the types of legal actions brought against those who murdered Emmitt Till and Trayvon Martin as well as the social policy regimes in which Black communities have their voice and authority weakened are the popular lay attitudes and beliefs characteristic of their fellow citizens: namely, White Americans. These individuals sit on juries, vote in elections, and hold critical decision-making positions. 
As a result, the characteristic modes of thought about the behavioral traits, status, and rights of members of marginalized racial groups held by such individuals may greatly influence behavior. Sociologist Alicia Simmons and I examine in detail one of the most widely used and influential political attitude scales-a measure of racial resentment (symbolic of modern racism in some discussions, see Kinder and Sanders 1996)—to better specify its meaning to respondents and theoretical import for scholars of race. The research uses both survey-based experiments in a national sample survey and extensive analysis of open-ended discursive explanations of respondent frames of reference. The results strongly suggest that racial resentment, while a complex of ideas involving values and liberal versus conservative outlooks (Krysan 2000), centers most heavily on issues of race, particularly ideas about whether Blacks are pressing demands that threaten to upset the established racial hierarchy through either their influence, political power, or unwarranted claims of discriminationbased disadvantage (see Samson and Bobo 2014). That is, the political, potent outlook labeled as "racial resentment" reflects as much, if not more, about struggles over "group position" and group threat than it does purely psychological anti-Black feelings.

Systems of racial inequality and repression generate lines of critique and challenge within communities so marginalized. This is a critical factor in why systems of racial inequality are in a constant state of adaptation and response. Such critiques and challenges vary enormously in their clarity, directness, political sophistication, and degree of open threat to a prevailing racial order. Sometimes this resistance is manifest in general cultural modes of expression. For example, hip hop and rap have often been depicted as aspects of urban Black youth culture that frequently invoke powerful critiques of inequality, racism, police violence, mass incarceration, segregation and so on (Morgan 2009; Morgan and Bennett 2011). Political scientists Lakeyta Bonnette-Bailey, Ray Block, and Haywood McClerking attempt a careful empirical assessment of how the consumption of hip hop music relates to political activism among Black youth. Their results suggest that those with the highest consumption of and most sophisticated take on the social critique often contained in hip hop are among the most likely to engage in politics beyond mere voting.

Several of the articles in this issue tackle patterns of individual adaptation and response to a stigmatized identity among Blacks and Latinx individuals. For example, education researchers Chasity Bailey-Fakhoury and Donald Mitchell explore the experience of African American mothers who have daughters in predominantly White schools. They observe that the mothers frequently encounter racial micro-aggressions. They identify several culturally grounded strategies of response to these microaggressions, but note that the constancy of the struggle results in a significant sort of "battle fatigue." The Black mothers' identities and actions are read through the lens of Du Bois's discussion of "the veil."

Sociologist Amanda Barrett Cox investigates the effects of a program designed to smooth the transition of Black youth into elite day and boarding schools. Her results suggest that, although emotionally challenging, the academic rigors the students are put through improve their confidence and sense that they can meet the challenges of these elite environments. One perhaps unexpected result is that this growing self-confidence re-enforced a very individualistic, non-structural take on the causes of personal success and failure. In a similar vein, sociologist Brandon Jackson examines how college educated Black men are trained in professional self-presentation in order to more effectively navigate White middle-class career and work spaces. Sociologist Sandra Susan Smith explores with in-depth interviews job-holders with respect 
to their willingness to help formerly incarcerated individuals obtain employment. She identifies two very distinct frames of thought regarding taking such action. One frame stresses the potential of all individuals to change. Another focuses on whether the previously incarcerated individual had effectively "signaled" a change in underlying patterns of behavior. Thus, a criminal record per se did not solely determine how others with job related social capital helped (or failed to help) a former convict seeking work.

As noted on several occasions above, racial identities intersect with a variety of other bases of social identity, particularly axes of class and of gender and sexuality. Two of the articles in this issue take up such conjuncture of positionality. Sociologist C. Shawn McGuffey examines via in-depth interviews with over one hundred LGBTQ African Americans whether and how they engage in disclosure about their identities and whether they regard Black civil rights as aligned with marriage equality rights. The results suggest that those who are more disclosing about sexual and gender identity tend to see more of a linkage between Black civil rights and marriage equality. Those who more selectively disclose see a larger separation between the two rights agendas and are concerned that the LGBTQ movement privileges the claims of Whites.

Cleve Tinsley, Pamela Prickett and Elaine Ecklund investigate the interaction of religion and class in how African Americans view the relationship between the church and science. The results in part confirm patterns observed in other research. Less well-educated Black Protestants tend to perceive greater tension between science and the church and religion. Yet, when it comes to science making specific health related contributions, the gaps in education among Black Protestants are much smaller.

The full sweep of the articles in this issue reminds us, first and foremost, that race and systems of racial inequality are not static conditions, nor uniformly expressed statuses, rather they are continuously negotiated and contested patterns of human social organization with often contextually variable meanings. To the extent racial division and inequality seem intractable, this is mainly traceable to the concept's ability to flexibly adapt to many challenges and changing circumstances. That successful flexibility is in part traceable to the unique capacity of notions about race to weave meaningful connections between self and social identities, interpersonal attitudes and outlooks, and racialized material divisions of power, status, and wealth.

\section{REFERENCES}

Bobo, Lawrence, James R. Kluegel, and Ryan A. Smith (1997). Laissez-Faire Racism: The crystallization of a Kinder, Gentler Anti-black Ideology. In Steven A. Tuch and Jack K. Martin (Eds.), Racial Attitudes in 1990s: Continuity and Change, pp. 23-35. Westport, CT: Praeger.

Kim, Claire Jean (1999). The Racial Triangulation of Asian Americans. Politics \& Society, 27(1): $105-138$.

Kinder, Donald R., and Lynn M. Sanders (1996). Divided by Color: Racial Politics and American Democracy. Chicago: University of Chicago Press.

King, Desmond, and Rogers Smith (2011). Still a House Divided: Race and Politics in Obama's America. Princeton, NJ: Princeton University Press.

Krysan, Maria (2000). Prejudice, Politics, and Public Opinion: Understanding the Sources of Racial Policy Attitudes. Annual Review of Sociology, 26: 135-168.

Morgan, Marcyliena H. (2009). The Real HipHop: Battling for Knowledge, Power, and Respect in the LA Underground. Durham, NC: Duke University Press.

Morgan, Marcyliena H., and Donnie Bennett (2011). Hip-Hop and the Global Influence of a Black Cultural Form. Daedalus, 140(2): 176-196. 
Pager, Devah, and Hana Shepherd (2008). The Sociology of Discrimination: Racial Discrimination in Employment, Housing, Credit, and Consumer Markets. Annual Review of Sociology, 34: 181-209.

Reskin, Barbara (2012). The Race Discrimination System. Annual Review of Sociology, 38: $17-35$.

Samson, Frank L., and Lawrence D. Bobo (2014). Ethnoracial Attitudes and Social Inequality. In J. McLeod, M Schwalbe, and E. Lawler (Eds.), The Handbook of the Social Psychology of Inequality, pp. 515-545. New York: Springer-Verlaine. 